\title{
Conceptions of Literacy in English Language Education Context:
}

\author{
EFL University Teachers' Perceptions
}

\author{
Salim Nabhan* \\ English Language Education Department \\ Universitas PGRI Adi Buana \\ Surabaya, Indonesia \\ *salimnabhan@unipasby.ac.id
}

\begin{abstract}
Conception of literacy, traditionally defined as the ability to read and write with printed texts, has grown beyond its narrowed views towards new understandings of multiliteracy due to the advancement of technology. Despite a plethora of study on general conception of literacy, little is known about the contemporary definition of literacy. To bridge the gap, this qualitative case study aims to identify the perception about the concept of literacy related to ELT from the perspective of EFL university teachers. In-depth interview process using purposeful selection of the participants of university teachers with a minimum 8-10-year teaching experience from one of the urban universities in Indonesia was involved. Additionally, focus group discussion and documents were also involved. After the interviews and focus group discussion, the data were analysed using a thematic analysis. Three main themes were identified: diverse perceptions regarding the concept of literacy, dimensions of literacy, and the demand of literacy-based English language education. Some participating teachers reported that the conception of literacy was perceived as traditional conception of literacy and merely focused on the core of English language skills such as reading and writing. However, the participants noted that literacy components dealt with critical literacy inclusion, the use of technology, and multimodal integration in the classroom practices. The teachers noted that literacy was essential in ELT with the implementation of certain pedagogy. The finding of the study might have implication to develop the literacy instruction in English language education setting which is relevant to the 21 st century education.
\end{abstract}

Keywords-literacy, multiliteracy, english language teaching, university teachers

\section{INTRODUCTION}

Traditionally, literacy is defined as the ability to read and write. In the 21-century education with its rapid growth of technology, the conceptions of literacy has shifted into expanded terms and definitions. Several terms have been proposed such as information literacy, multiliteracies, new literacy, digital literacy, and web literacy [1]. In other words, today's literate learners are much different from those of students from a decade ago. Moreover, today's learners are considered as digital natives in which they possess the ability to use digital technology [2]. Hence, these new perspectives bring about the implication in teaching and learning practices.

Several studies [1-8] have suggested some features in contemporary definition of literacy including 1) oral and/or written communication focusing on meaning (e.g., meaning negotiation rather than linguistic form), 2) a wide variety of abilities of communication (e.g., reading, speaking, writing, etc., 3) a dynamic set of sub-abilities (e.g., analysing, collaborating, problem solving, etc.), 4) a dynamic set of socially, historically, and culturally situated practice (e.g., technological report), 5) multiple forms of texts and multimodalities (e.g., audio, visual, etc.), 6). Out of school textual language experiences (e.g., chatting, browsing, etc.). However, in English language education context, there was still misconception of literacy limited only to the core of English skills such as reading and writing [9]. Moreover, the teachers' perception toward literacy might affect their pedagogical approaches in their classroom.

Despite the recent growth of studies related to the conception of literacy, little attention has been given to the area of English language education which is contextualized with the contemporary notion of literacy. To bridge the gap, this study aims to identify the perception about the concept of literacy that is related to ELT from the perspective of EFL university teachers.

\section{MethodS}

This research involved qualitative case study approach to address the research problem related to EFL university teachers' conception literacy in English language education context. Participants were EFL teachers in English Language Education Department at one of urban universities in Indonesia. As university teachers, they have gained minimum master's degree in majoring English Language Education or Literature. Moreover, they have been teaching English for 8-10 years in different courses such as Speaking, Listening, Reading Comprehension, English Grammar, CALL, Literature in ELT, 
etc. The university teachers as participants were selected to provide and contribute deeper collective views and comprehensive perspectives based on their actual personal knowledge and experiences.

Since this study used qualitative case study approach, methodological triangulation was utilized including interviews, focus group discussion, and documents. Following Guest et al. [10], six participants were interviewed for approximately 25 minutes where questions focused on their perceptions regarding the conception of literacy in their respective fields. As an attempt to obtain the further details, one 4-member focus discussion was administered upon completion of individual interviews. The focus group questions were as follows:

- Based on your own understanding, would you define and describe what literacy is?

- What does it mean to be "literate person"?

- What are some aspects/dimensions of literacy such as critical literacy, digital literacy etc.? Would you explain them

- Do you agree to integrate literacy in English language teaching? Please give the reasons

Additionally, study on documents was also done through the teachers' lesson plans. Before participating the research, participants were provided with the explanation related to the objectives of the study and other relevant information. The researcher also gave the written consent to ensure that the participants acknowledged the research [11]. Additionally, the data from the participants were recorded and transcribed for member checking. Related to data analysis, the qualitative data were analysed using thematic analysis. The data derived from the participants' interviews and focus group discussions were developed into codes and grouped them into categories. Finally, the researcher identified the themes based on the research problem. This process generated three main themes and provided sample data to support the themes. The themes are diverse perception regarding the concept of literacy, dimensions of literacy, and the demand of literacy-based English language education. Moreover, member checking was also conducted for data validity of the research findings [11].

\section{RESULTS}

Three main themes were identified: diverse perception regarding the concept of literacy, dimensions of literacy, and the demand of literacy-based English language education.

\section{A. Diverse Perceptions about the concept of literacy}

The understanding of literacy tended to adopt the skillsbased perceptions. The most dominant conception of literacy was associated with the ability to read and write and other set of functional skills such as being critical and problem solving. A skill-based conception was reflected in a response such as: "The person who is able to read, understand and to be critical about text and the context." Additionally, a teacher stated,
"Literacy is one's ability to read, write, speak, count and solve problems that need special skills in the daily life." In this case, typical skills mentioned were related to the core skills such as reading, writing, speaking, counting, and problem solving.

In English language context, a participant established the definition of literacy with the core skills of English focusing on the reading and writing skills. A response typical of this issue included: "Literacy is ability to read and write (in English). Not only know the meaning and how to pronounce the words, but also understand the information literally, do interpretation of what we have already read, and make a meaningful writing." In this setting, more specifically, the skill of reading embraced the ability to comprehend the texts, while writing involved the production of idea.

\section{B. Dimensions of Literacy}

Teachers indicated several dimensions or aspects of literacy encompassing critical literacy inclusion, use of technology, and multimodality integration.

1) Critical literacy inclusion: Being critical as one aspect of literacy was explained by the participants. A participant stated, "Critical literacy means having ability to solve problems critically..." Moreover, another teacher further elaborated the strategies of thinking critically as follows:

With critical literacy, we are not only able to understand the implicit meaning but also the explicit of an information provided. Collecting some supporting facts of what we are thinking for the information is the way to criticize and share our thinking.

This response emphasized that critical thinking was needed to comprehend the meaning both deep and surface structures. Additionally, thinking critically was also dealing with understanding facts.

2) The use of technology: Another aspect of literacy is associated with the use of technology. The individual competences of utilizing technology was so called digital literacy. It was reflected in a response of a teacher: "... while digital literacy is the ability of using technology to solve life problems." Typical of this statement was explained by another participant: "Digital literacy is being fluency about digital world."

In particular, a teacher explained more specific on how to be digitally literate students as follows:

Digital literacy brings us to be a fully user of digital devices. Understanding how to operate laptop, mobile phone, tablet, PC, etc. and the use of software inside are a means of gadget literate. Digital literacy is developed into media literacy which we have to be a social media literate.

Digital literacy competencies that this teacher wanted to identify reflected the ability to operate devices and media. "We have to be able to get, analyse, and criticize the knowledge and information's in social media; have fabulous writing in social 
media; and have an ability in email correspondence," she added.

3) Multimodality integration: At the same time, participants also included multimodality as part of literacy. In the English language teaching and learning setting, using multiple modes of media such as audio, visual, spatial, etc. or a combination of them was necessary to motivate the students. A teacher illustrated with the following response:

Game application is not a strange thing in English teaching and learning. Most of teachers frequently use many kinds of interesting games in their class, and their students are very happy in participating the English class. With game literacy both at home and in class can help the students to solve the problem, making tactics, etc.

Moreover, during the pandemic, the teachers were forced to shift their teaching from face to face into virtual meeting. Hence, they were required to prepare the materials digitally. A teacher stated, "I set the materials for online classes using Learning Management System (LMS) provided by the university. I upload my teaching materials in PDF format. I sometimes use YouTube video." This explanation demonstrated that they have integrated multiple modes of teaching media not only in written forms but also recorded pictures and sounds.

In addition, the data were also supported by the study of documents. Through the teachers' artifacts of lesson plans, it was found that participants included multimodality in the media used in their teaching practices such as images, audio and video.

\section{The Demand of Literacy-based English Language Education}

Seen from the context of English language education, teachers expressed their growing awareness of the importance of literacy. The need of multiliteracies pedagogy is inevitable in today's $21 \mathrm{st}$ century education. A teacher stated: "Integrating literacy is a need in industrial revolution 4.0 and in the future. It means that we should combine all skills". Further, another teacher explained, "As we know that technology can enhance the language learning process. With technology teachers can provide more authentic and interesting materials that can inspire students."

Moreover, teachers should integrate literacy in their teaching and learning process as explained by one of the participants as follows:

Both teacher and student can be in the same literacy atmosphere. The teacher is a role model that has a huge opportunity to push and help their students to be a literate student with their ability in giving example as a literate teacher and using many kinds of developed literacy activities in the class. The student also takes an important part in order to have a meaningful literacy atmosphere by applying literacy strategies and critical thinking in literacy.

\section{DISCUSSION}

The basic understanding of literacy was found to be wellrepresented by the teachers as a set of core skills including the ability of reading and writing. However, some other features of contemporary definition of literacy were not presented. In other words, the teachers' perception of the literacy was in the surface level. Several recent studies $[1,12,13]$ suggested that conception of literacy have shifted into multiple directions beyond the ability of reading and writing. Moreover, with the advancement of technology nowadays, literacy was also reflected to the technology utilization along with the competences of collaboration, problem solving, and multimedia production. These conceptions reflect the contemporary definition of $21^{\text {st }}$ century literacy skills. Less understanding toward the comprehensive conceptions of literacy might have implication to the teachers' literacy development and eventually affect to their teaching practices. Therefore, the misconception of teaching English focusing only on the English core skills should be avoided [9].

Notwithstanding the basic understanding of literacy, the teachers reported the critical thinking as one of the aspects of literacy. Thinking critically was understood as the ability to understand and analyse the texts and contexts. This demonstrates the importance of critical literacy to be integrated in the English teaching and learning process through several methods and techniques. This finding is in line with some studies suggesting that critical thinking should be an essential outcome of university level education and engaged in the emergence of technological issues [14-17].

With reference to the dimensions of literacy comprising digital literacy. In general, this finding echoes several studies regarding the digital literacy framework [5-8,18-21]. The studies suggested sets of skills to possess to be digitally literate individuals such as critical thinking, tech savvy, technical skills, collaboration, communication, creativity, functional skills, and searching information. However, they were still insufficient in defining digital literacy. In other words, the key insight emerges from the study is that digital literacy was identified to be the ability to utilize the technology. Indeed, digital literacy education is necessary as one part of teachers' professional development.

Multimodality included as other dimension of literacy was practiced by the teachers. The involvement of multiple modes in the teaching and learning activities such as the use of audio visual demonstrated the multiliteracies pedagogy. Pedagogy of Multiliteracies was introduced to adapt the advancement of technology utilizing multimodality [4,22-24]. Moreover, today's learners are considered as digital natives [2], and therefore, the nature of learning has shifted from print based into digitalization [9]. An additional point to emerge from this study is that teachers should follow the rapid growth of technology and adopt them in their teaching practices.

As a final point, the teachers came to realize the important of literacy to be integrated in English language education. Teaching English is not merely teaching the core language 
skills such as listening, speaking, reading, and writing, but also other competences in order that learners can face the world. Multiliteracies pedagogy was promoted to bridge the gap. Several studies [25-29] have shown the implementation of literacy-based English language education and proven to give benefits for the learners. In addition, Nabhan [30] has proposed multiliteracies and process approach framework in teaching English writing.

\section{CONCLUSION}

The study has identified the conceptions of literacy from the perspective of EFL university teachers in English language setting. The finding revealed three main themes including diverse perception regarding the concept of literacy, dimensions of literacy, and the demand of literacy-based English language education. Some teachers reported lack understanding of comprehensive conception of literacy. However, the participants performed the literacy aspects comprising critical literacy, the use of technology, and multimodal integration in their English classroom practices. The teachers agreed that literacy-based education is necessary with certain pedagogies. Taken all together, the finding suggests that literacy has an important space in English language education especially in facing the 21 st century challenges.

\section{ACKNOWLEDGMENT}

The presentation of this paper at the conference was funded by Universitas PGRI Adi Buana Surabaya, Indonesia.

\section{REFERENCES}

[1] J. Pilgrim and E.E. Martines, "Defining Literacy in the 21st Century: A Guide to Terminology and Skills," Texas J. Lit. Educ., vol. 1, no. 1, pp. 60-69, 2013.

[2] M. Prensky, "Digital Natives, Digital Immigrants," in From Digital Natives to Digital Wisdom: Hopeful Essays for 21st Century Learning, 2014.

[3] C. Assessment, "What is literacy? An investigation into definitions of English as a subject and the relationship between English, literacy and " being literate ' A Research Report Commissioned by Cambridge Assessment," 2013

[4] B. Cope and M. Kalantzis, "Multiliteracies ": New literacies , new learning," Pedagog. An Int. J., vol. 4, no. 3, pp. 164-195, 2009, doi: 10.1080/15544800903076044.

[5] C. Hague and S. Payton, Digital literacy across the curriculum: A futurelab handbook. Bristol, UK: Futurelab, 2010.

[6] A. Ferrari, DIGCOMP : A Framework for developing and understanding digital competence in Europe . Joint Research Centre of the European Commission, 2013.

[7] D. Belshaw, The essential elements of digital literacies. 2015.

[8] S. Carretero, R. Vuorikari, and Y. Punie, DigComp 2.1: The Digital Competence Framework for Citizens. 2017.

[9] S. Nabhan and R. Hidayat, "Investigating literacy practices in a university EFL context from multiliteracies and multimodal perspective : A case study," Adv. Lang. Lit. Stud., vol. 9, no. 6, pp. 192-199, 2018, doi: http://dx.doi.org/10.7575/aiac.alls.v.9n.6p.192.
[10] G. Guest, A. Bunce, and L. Johnson, "How many interviews are enough? An experiment with data saturation and variability," Field methods, vol. 18, no. 1, pp. 59-82, 2006, doi: $10.1177 / 1525822 \times 05279903$.

[11] A. Mackey and S. M. Gass, Second language reseacrh: Methodology and design. New Jersey: Lawrence Erlbaum Associates, 2005.

[12] M. Shoffner, L. C. de Oliveira, and R. Angus, "Multiliteracies in the secondary english classroom: Becoming literate in the 21st century," English Teach. Pract. Crit., vol. 9, no. 3, pp. 75-89, 2010.

[13] S. Abdulatief, X. Guzula, C. Kell, G. Lloyd, P. Makoe, C. McKinney, and R. Tyler, "How are we failing our children? Reconceptualising language and literacy education," 2018.

[14] S.C. Kong, "Developing information literacy and critical thinking skills through domain knowledge learning in digital classrooms: An experience of practicing flipped classroom strategy," Comput. Educ. vol. 78, pp. 160-173, 2014, doi: 10.1016/j.compedu.2014.05.009.

[15] L. Hutchinson and M. Novotny, "Teaching a Critical Digital Literacy of Wearables: A Feminist Surveillance as Care Pedagogy," Comput. Compos., vol. 50, pp. 105-120, 2018, doi: 10.1016/j.compcom.2018.07.006.

[16] K.Y.L. Ku, Q. Kong, Y. Song, L. Deng, Y. Kang, and A. Hu, "What predicts adolescents' critical thinking about real-life news? The roles of social media news consumption and news media literacy," Think. Ski. Creat., vol. 33, no. May, p. 100570, 2019, doi: 10.1016/j.tsc.2019.05.004.

[17] M. Goodsett, "Best practices for teaching and assessing critical thinking in information literacy online learning objects," J. Acad. Librariansh., vol. 46, no. 5, p. 102163, 2020, doi: 10.1016/j.acalib.2020.102163.

[18] A. Calvani, A. Cartelli, A. Fini, and M. Ranieri, "Models and instruments for assessing digital competence at school," $J$. e-learning Knowl. Soc., vol. 4, no. 3, pp. 183-193, 2008, doi: 10.20368/1971$8829 / 288$

[19] M. Khosrow-pour, "Encyclopedia of information science and technology, third edition," Encycl. Inf. Sci. Technol. Second Ed., vol. i, 2010, doi: 10.4018/978-1-60566-026-4.

[20] Jisc, “Developing students' digital literacy,” 2015.

[21] J.-B. Son, “Digital Literacy,” 2015.

[22] NLG, "A pedagogy of multiliteracies : Designing social futures," Harv. Educ. Rev., vol. 66, no. 1, pp. 60-92, 1996.

[23] C. Jewitt, "Multimodality, 'reading' and 'writing' for the 21 st century," Discourse Stud. Cult. Polit. Educ., vol. 26, no. 3, pp. 315-331, 2005 , doi: 10.1080/01596300500200011.

[24] J. Álvarez, "Meaning making and communication in the multimoda age : ideas for language teachers," Colomb. Appl. Linguist., vol. 18, no. 1, pp. 98-115, 2016, doi: http://dx.doi.org/10.14483/calj.v18n1.8403.

[25] S. Nallaya, "the Impact of Multimodal Texts on the Development of English," no. February, 2010.

[26] W.C. Sewell and S. Denton, "Multimodal literacies in the secondary English classroom," English J., vol. 100, no. 5, pp. 61-65, 2011.

[27] L. Ajayi, "How teachers deploy multimodal textbooks to enhance English language learning," TESOL J., vol. 6, no. 1, pp. 16-35, 2012.

[28] A.M. Smith, "Multimodal literacy in the English / language arts classroom: Meeting standards and remaining relevant in the $21 \mathrm{st}$ century," The College at Brockport: State University of New York, 2014

[29] C. Warner, D. Richardson, and K. Lange, "Realizing multiple literacies through game-enhanced pedagogies: Designing learning across discourse levels," J. Gaming Virtual Worlds, vol. 11, no. 1, pp. 8-29, 2019, doi: 10.1386/jgvw.11.1.9.

[30] S. Nabhan, "Bringing multiliteracies into process writing approach in ELT classroom: Implementation and reflection," EduLite J. English Educ. Lit. Cult., vol. 4, no. 2, p. 156, Sep. 2019, doi: 10.30659/e.4.2.156-17 